\title{
LITERASI DIGITAL PEREMPUAN PADA ORGANISASI PER- SATUAN ISTRI PRAJURIT (PERSIT)
}

\author{
Desy Erika \\ desyerika@stikomsemarang.ac.id \\ Program Studi Ilmu Komunikasi STIKOM Semarang
}

\begin{tabular}{l} 
Article Info \\
\hline Keyword: \\
$\begin{array}{l}\text { Digital literacy ; } \\
\text { organization, Movement }\end{array}$
\end{tabular}

\section{PENDAHULUAN}

Literasi Digital perempuan menjadi persoalan krusial dalam kajian feminis sains dan teknologi. Perempuan disebut sebagai target potensial dalam literasi digital terutama ibu - ibu, dalam tulisannya Rahmiaji (2019) menyebutkan beberapa kasus yang melibatkan perempuan khususnya ibu - ibu dalam media sosial menjadi kontroversial sehingga menumbuhkan situasi yang mencemaskan. Salah satunya, fenomena yang sempat viral 11 oktober 2019 lalu, mengenai Dandim kendari dan beberapa anggota TNI AD yang dicopot dari jabatannya karena beredarnya postingan media sosial istri terkait penusukan Wiranto yang diindikasi- kan sebagai ujaran kebencian.

Penelitian ini tidak bertujuan untuk melihat kasus tersebut secara mendalam namun mencoba mendeskripsikan literasi digital pada perempuan disini anggota organisasi Persatuan Istri Prajurit (PERSIT) Kartika Chandra Kirana TNI AD.

Organisasi PERSIT menjadi menarik dan relevan untuk diteliti dalam perspektif gender dan literasi digital karena persit merupakan organisasi yang kohesif, organisasi ini terdiri dari istri - istri prajurit dan istri pegawai negeri sipil TNI AD yang secara tidak langsung melekat budaya hirarki militer yang masih kuat. Selain itu, persit terdiri dari perempuan dengan latar belakang budaya, pendidikan dan status sosial yang heterogen. Organisasi PERSIT Skadron 31 PUSPENERBAD dipilih dalam penelitian ini karena secara aktif melakukan sosialisasi mengenai literasi 
digital pada anggotanya.

Upaya yang dilakukan oleh organisasi PERSIT Skadron 31 bertujuan untuk menghindari anggota PERSIT dari penyalahgunaan dan dampak negative media digital, dan diharapkan dapat mengakses, mengintepretasikan, menganalisis dan mengevaluasi informasi, serta membangun pengetahuan baru yang produktif dalam kehidupan organisasi PERSIT.

Model literasi digital perempuan yang dilakukan pada organisasi PERSIT berbeda dengan metode literasi digital pada organisasi perempuan pada umumnya.

Sistem Hirarki militer berupa kepemimpinan otoriter, senioritas dan junioritas, serta pengawasan yang menyasar secara personal masih menjadi budaya dalam organisasi PERSIT, maka tidak heran jika penyalahgunaan media sosial pada perempuan, anggota persit bukan hanya berimplikasi pada dirinya sendiri namun juga pekerjaan suaminya yang notabene adalah anggota TNI AD .

Dengan menemukan model kegiatan yang efektif akan terjadi optimalisasi literasi digital yang berfokus pada perempuan dan hal ini berlandaskan pada perspektif gender.

Penelitian terkait literasi digital perempuan telah banyak dilakukan seperti penelitian yang dilakukan oleh Widyastuti, Nuswantoro (2016) mengenai literasi digital pada perempuan pelaku usaha produktif yang berfokus pada penggunaan media digital untuk meningkatkan perekonomian, selain itu penelitian Rai (2019) yang berjudul "Digital Divide How Do Women in South Asia Respond?" mengenai kesenjangan penggunaan digital perempuan dan laki - laki yang cukup signifikan pada beberapa Negara di Asia. Kebanyakan penelitian yang sudah ada berorientasi pada identifikasi literasi digital perempuan yang berfokus pada pemberdayaan perempuan dan kesenjangan digital gender.

Berbeda dengan penelitian - penelitian literasi digital dalam perspektif gender yang pernah dilakukan sebelumnya. Penelitian ini akan menggambarkan (1) Bagaimana aktivitas atau kegiatan literasi digital yang dilakukan oleh organisasi PERSIT (2) Bagaimana kompetensi atau kemampuan literasi digital perempuan, anggota PERSIT dalam penelitian ini adalah organisasi PERSIT Kartika Chandra Kirana pada Skadron 31/ SERBU PUSPENERBAD Semarang.

Tulisan ini bertujuan untuk memaparkan hasil penelitian yang merupakan serangkaian usaha ilmiah dan akademis untuk menggambarakan literasi digital perempuan yang ada berbasis gender pada Organisasi PERSIT Kartika Chandra Kirana Skadron 31 Puspenerbad Semarang.

\section{KAJIAN PUSTAKA}

\section{Metodologi}

Penelitian ini mengkaji tentang literasi digital perempuan, subjek penelitian ini adalah pengurus dan anggota organisasi Persatuan Istri Prajurit (PERSIT) TNI AD Kartika Chandra Kirana pada Skadron 31/ SERBU PUSPENERBAD Semarang. Subjek dipilih secara sengaja (purposive sampling) merupakan perempuan, yaitu anggota persit yang aktif menggunakan internet dan telah mengikuti kagiatan PERSIT yang terkait dengan literasi digital. Subjek penelitian tersebut dijadikan informan utama atau sumber data utama.

Paradigma penelitian ini adalah paradigma postpositivisme. Paradigma postpositivisme ialah paradigma dimana kebenaran suatu realitas sosial dilihat sebagai kebenaran subjektif dan tergantung pada konteks dan value, kultur, tradisi, kebiasaan dan kebenaran suatu realitas sosial bersifat relatif.

Penelitian ini menggunakan pendekatan kualitatif dengan menggunakan studi atau metodologi deskriptif kualitatif . Studi deskriptif adalah metode yang melukiskan suatu keadaan objektif atau peristiwa tertentu berdasarkan fakta - fakta yang tampak atau sebagaimana mestinya yang kemudian diiringi dengan upaya pengambilan kesimpulan umum (Nawawi and Martini, 1994)

Dalam penelitian ini berusaha memahami dan mempelajari literasi digital perempuan dalam konteks kegiatan dan kompetensi literasi digital anggota organisasi PERSIT . Teknik pengumpulan data yang digunakan adalah wawancara mendalam dengan 6 in- 
forman perempuan, merupakan anggota persit skadron 31 puspenerbad Semarang untuk menggali informasi dan persoalan dari subjek sasaran dan observasi partisipatif dengan mengamati dan berpartisipasi langsung pada kegiatan literasi digital yang dilakukan oleh organisasi PERSIT dan melihat aktivitas media sosial informan

Selanjutnya dalam penelitian ini adalah melakukan teknik analisis data dimulai dengan analisis secara kualitatif terhadap hasil wawancara, kemudian dilakukan interpretasi secara mendalam mengenai hubungan antara teori dan fakta yang terjadi. Disini juga mengikutsertakan kutipan - kutipan (direct quotations) dari para informan. Sementara hasil data observasi digunakan sebagai pelengkap dan pembanding dari data wawancara yang dikumpulkan sekaligus untuk triangulasi data menguji keabsahan data.

\section{Kajian Konseptual}

Isu Literasi digital gender terutama pada perempuan telah menjadi isu yang cukup penting untuk dikaji, terutama melihat jumlah bonus demografi dan jumlah penetrasi internet di Indonesia.

Dalam pengertiannya literasi digital berarti memiliki keterampilan yang tepat dalam menggunakan teknologi digital untuk mencapai tujuan. Keterampilan digital meliputi pengetahuan dan kemampuan seputar atribut teknologi digital yang memungkinkan individu untuk meningkatkan potensi belajar, kehidupan dan pekerjaan mereka di era digital (Rai, 2019).

Sejalan dengan itu Hobbs (2010) membagi literasi digital dalam lima kompetensi sebagai berikut; (1) kompetensi akses yaitu individu terampil dalam menggunakan platform dalam media digital dan berbagi informasi yang relevan dengan orang lain, (2) menganalisis dan mengevaluasi, individu memiliki kompetensi memahami pesan dan kritis dalam menilai dan menganalisis kualitas pesan dilihat dari kebenaran, kredibilitas dan sudut pandang pembuat pesan, serta mampu memahami efek dan konsekuensi yang ditimbulkan dari sebuah pesan, (3) memproduksi, kompetensi ini mencakup kemampuan individu dalam menulis dan menghasilkan konten menggunakan kreativitas dan mampu memproduksinya dengan teknik yang sesuai dengan platform media digital sesuai dengan pesan, audiens dan tujuannya, (4) refleksi, memproduksi dan mendistribusikan konten sesuai dengan etika dan budaya yang berlaku serta memiliki tanggung jawab secara sosial. (5) berkolaborasi, kemampuan individu untuk berkolaborasi dan berpartisipasi dalam lingkungan keluarga, social dan komunitas untuk berbagai pengetahuan dan memecahkan masalah pada tingkat lokal, regional, nasional dan internasional.

Dalam tulisannya Andreas Maryoto dikutip dalam Rahmiaji (2019) "Literasi Ibu Rumah Tangga Mencemaskan" Indonesia berada pada urutan kedua terakhir dalam1.56 negara, yang berarti masih rendahnya literasi digital perempuan di Indonesia.

Pada tahun 2018, survey APJII menunjukan alasan utama orang Indonesia menggunakan internet adalah untuk chatting atau komunikasi lewat pesan sebesar $1.54,7 \%$ dan social media sebesar 18,9\%. Penelitian lain dikutip dari laporan daily social id (2018) menyatakan bahwa informasi hoax paling banyak ditemukan dalam platform media sosial, facebook 82,25\%, WhatsApp 56,55\%, dan instagram 1.59,48\%. Sebagian besar responden sebesar 44,19\% tidak yakin memiliki kepiawaian dalam mendeteksi berita hoax dan 51,03\% dari responden memilih untuk berdiam diri dan tidak percaya dengan informasi ketika menemui berita hoax. Sejalan dengan itu Eli Pariser menyatakan bahwa algoritma yang digunakan platform media sosial disebut filter bubble membuat pengguna media sosial hanya melihat apa yang ingin dilihat dan membaca, apa yang ingin dibaca. Hal ini menyebabkan pengguna media sosial seolah hidup di dalam ruang bergema (echo chamber) yang senantiasa meyakini pandangannya sebagai yang paling benar dikarenakan konten - konten yang memang dipilihkan sesuai preferensi pribadinya (Banyumurti, 2019).

Dalam kaitannya dengan penelitian ini, perempuan dalam organisasi PERSIT adalah agen perubahan penting dalam literasi digital mengingat peran perempuan dalam domestik keluarga, terutama dalam pola mengasuh anak. Tantangan dalam era digital semakin besar bagi perempuan, disatu sisi media digital memberikan berbagai macam kemudahan dan kesempatan baru, namun disisi yang lain media digital menyimpan 
berbagai ancaman bagi penggunanya.

Perempuan dengan literasi digital yang rendah akan memberikan dampak buruk bagi perkembangan anak. Seperti yang diungkapkan oleh Herlina at.el. (2018) mengungkapkan bahwa kemahiran generasi dalam media digital ditentukan oleh berbagai faktor, antara lain terpaan teknologi digital, tingkat pendidikan ibu, dan tingkat ekonomi keluarga. Oleh sebab itu pentingnya perempuan perlu membekali diri dengan literasi digital yang mumpuni.

Jika perempuan sudah diperkenalkan dengan kompetensi dalam literasi digital, maka konsep selanjutnya yang harus dipaparkan adalah pengembangan organisasi, dalam hal ini organisasi PERSIT yang berperspektif gender. Konsep yang memadukan antara gender dan informasi teknologi mulai berkembang pada akhir tahun 1980-an dan 1990-an dengan istilah cyberfeminism, perkembangan teknologi yang cepat menyebabkan teori ikut berkembang sebagai respon yang dinamis atas perubahan perilaku (Rosser, 2005).

Menurut Rosser (2005) dalam perspektif gender dan teknologi informasi saat ini terdapat beberapa hal yang digugat, antara lain kesenjangan akses internet dan penggunaan teknologi antara pria dan wanita. Penggunaan teknologi pada wanita sebatas pada penggunaan yang bersifat konsumtif dan hiburan, seperti menggunakan media sosial untuk pertemanan dan update status, sedangkan pria lebih berkontribusi dalam hal teknis dan produktivitas, seperti memahami kodding dan membuat aplikasi.

Merujuk pada riset Japelidi dalam Kurnia and Astuti (2017) kegiatan literasi digital paling banyak dilakukan oleh perguruan tinggi dan persentasi paling kecil pada profesi, asosiasi, ormas dan media.

Sejalan dengan itu Kurnia and Astuti (2017) menyatakan bahwa Ragam kegiatan literasi digital sangat penting dipetakan untuk mengidentifikasi (1) cara pandang terhadap solusi literasi digital; dan (2) model/ ragam kegiatan dominan maupun yang belum banyak dieksplorasi untuk mengampanyekan literasi digital.

Organisasi PERSIT Skadron 31 Puspenerbad Semarang adalah salah satu organisasi yang telah melakukan kegiatan literasi digital pada anggotanya.
Dalam komunikasi organisasi dan kegiatan sosialisasi faktor penting yang perlu dikaji adalah efektivitas komunikasinya. Menurut Goyer nilai efektivitas komunikasi dikatakan sempurna jika perbandingan makna yang di maksud pengirim sama dengan makna yang ditangkap penerima (Tubbs and Moss,2000). Dalam kaitannya dengan penelitian ini efektifitas komunikasi dari kegiatan literasi digital yang telah dilakukan oleh organisasi PERSIT dapat dilihat dari aspek kompetensi literasi digital yang dimiliki oleh anggotanya.

\section{TEMUAN DAN DISKUSI}

Organisasi yang menjadi gambaran dalam kajian ini adalah organisasi Persatuan Istri Prajurit (PERSIT) Kartika Chandra Kirana ranting 5 Skadron 31/ SERBU PUSPENERBAD Semarang.

PERSIT merupakan organisasi formal, memiliki struktur organisasi dan program kerja yang terencana dan terstruktur. Seluruh anggota persit tanpa terkecuali diwajibkan untuk menaati peraturan yang berlaku.

Kenyataannya dilapangan, peraturan tersebut bukan hanya mengatur jalannya organisasi secara formal, namun juga secara personal masing - masing anggotanya.

Secara substansi dari ke- 4 informan anggota persit Skadron 31 Puspenerbad belum pernah mendengar dan mengerti mengenai istilah literasi digital, namun mereka mengaku faham mengenai melek digital dan mempergunakan media digital dengan "bijak"

Sosialisasi literasi digital pada organisasi PERSIT diawali dari surat edaran kepada masing -masing kesatuan TNI AD dari cabang hingga ranting mengenai pentingnya etika dalam penggunaan media sosial, selain itu sosialisasi ini juga di sampaikan secara lisan oleh ketua kepada seluruh anggota persit pada forum pertemuan anggota. Seperti yang diungkapkan informan perempuan, anggota persit seperti berikut:

"perintah secara lisan selalu diperingkatkan agar menggunakan media digital dengan bijak intinya kita tidak boleh menyikapi media secara gampang, secara blak - blakan dicermati dulu sebagai insan jadi lebih bijak lagi untuk membaca segala jenis berita, tidak langsung menanggapi secara mentah".(anonym, wawancara 6 agustus, 2019) 
Sosialisasi literasi digital pada organisasi persit skadron 31 disampaikan secara sepintas pada forum pertemuan anggota pada tanggal 13 Februari 2019. Ketika itu, Bapak Letkol Cpn Sundoro Agung Nugroho selaku komandan dan pembina persit beserta Ibu Devita Sundoro selaku ketua persit menyampaikan agar setiap anggota senantiasa untuk dapat menggunakan media digital terutama media sosial dengan bijak, dengan tidak memposting foto atau status yang dapat merusak nama baik diri sendiri dan institusi TNI AD. Beliau juga menyampaikan agar di masa kampanye pilpres saat itu, persit tidak ikut terbawa dalam hiruk pikuk berita - berita hoax yang mendukung satu golongan tertentu sehingga menimbulkan kontroversi.

Bukan tanpa alasan organisasi PERSIT dalam sosialisasi literasi digital lebih menekankan kepada tujuan untuk menjaga image atau nama baik institusi karena disadari atau tidak anggota PERSIT akan menjadi representasi dari institusi TNI AD secara umum.

Secara garis besar kegiatan literasi digital yang telah dilakukan oleh skadron 31 puspenerbad lebih kepada sosialisasi umum yang lebih menekankan pada etika penggunaan media sosial terutama dalam menjaga citra dari konstitusi TNI AD seperti, tidak diperkenankan berfoto dengan gaya aneh - aneh salah satunya "melet" mengeluarkan lidah ketika mempergunakan baju seragam persit.

Selain itu, upload foto dan status yang dapat mencoreng nama baik suami dan institusi TNI AD. Seperti yang diungkapkan informan, anggota persit sebagai berikut :

"Lebih menjaga etika di medsos karna membawa nama suami dan institusi, lebih hati-

hati."'(Yolanda,wawancara 10 agustus, 2019)

Temuan ini sejalan dengan penelitian yang dilakukan oleh japelidi dalam Novi and Astuti (2017) yang menyatakan bahwa kegiatan literasi digital di Indonesia masih didominasi oleh bentuk kegiatan sosialisasi/ ceramah karena tergolong tidak terlalu rumit persiapannya dan durasinya tidak panjang, namun model ini cenderung satu arah dimana kendali dipegang penuh oleh moderator atau nara sumber, sehingga eksplorasi terhadap hal - hal yang belum jelas pun dikerangka bukan kepada kepentingan peserta.

Tidak dapat dipungkiri bahwa budaya militer turut mewarnai budaya organisasi persit terutama budaya otoritas dan senioritas yang masih kuat. Perasaan bangga bergabung dalam organisasi persit membuat setiap anggota memiliki semangat kelompok yang tinggi dan hubungan interpersonal yang akrab satu sama lain.

Dalam kelompok kohesif seperti persit, anggota anggotanya cenderung lebih mudah untuk tunduk pada norma kelompok, dan semakin tidak toleran kepada anggota yang devian (menyimpang)

(Rakhmat,2015).

Dalam literasi digital perempuan anggota persit saling mengingatkan satu sama lain untuk mejaga image dan wibawa mereka sebagai seorang istri prajurit di media sosial.

Jika ada anggota yang terbukti tidak sesuai dalam menggunakan media sosial, sehingga dapat merusak citra organisasi, maka kejadian ini akan disosialisasikan untuk menjadi contoh yang tidak baik dan tidak patut untuk ditiru.

Beberapa kasus bagi anggota yang terbukti melanggar, akan dikenakan sanksi bukan hanya teguran bagi dirinya sendiri, tapi juga sanksi bagi suaminya yang notabane merupakan prajurit TNI AD.

Selain itu rasa menjadi senior dengan jabatan atau pangkat suami yang lebih tinggi membuat anggota persit merasa menjadi "role model" bagi junior dan anggotanya, sehingga lebih mengontrol diri untuk mempergunakan media sosial. Hal ini tercermin dari ungkapan informan perempuan, anggota persit sebagai berikut:

"Biasanya langsung dikasi tau sesama anggota, kalau pake baju persit jangan gaya yang aneh - aneh. main tiktok juga jangan, ya jaga wibawa aja. jadi pikirannya masa istri tentara gaya fotonya kayak gitu, pake bajunya persit lagi. mungkin kalau baju bebas ya gak papa"

( Yolanda, wawancara 10 agustus 2019)

“ Kalau sekarang ngerasanya udah senior, jadi malu aja sama junior karna udah jadi contoh buat junior, masak kelakuan kita di medsos terutama gak sesuai, (Dai, Wawancara 11 Agustus 2019) 
Dalam literasi digital perempuan pada organisasi persit, pemimpin atau ketua manjadi faktor penting dalam kegiatan literasi, hal ini berkaitan dengan budaya organisasi hierarki militer dari atas kebawah yang bersifat otoriter dimana sebagian besar keputusan dan kebijakan seluruhnya ditentukan oleh pimpinan.

Dalam hal ini pemimpin yaitu Ibu Ketua Persit menjadi orang utama yang memberikan arahan kepada anggota menuju perubahan. Ketua Persit bukan hanya menjadi opinion leader dan pengawas tetapi juga menjadi contoh bagi anggotanya.

Dibawah kepemimpinan Ibu Devita Sundoro selaku Ketua Persit Skadron 31, kegiatan literasi digital lebih terasa dibandingkan kepemimpinan sebelumnya. Ibu Ketua sekarang lebih progresif dalam meberikan peringatan dan teguran terkait penggunaan media sosial, selain itu beliau sendiri mencoba memberikan contoh dengan tidak menggunakan media sosial secara aktif untuk eksistensi diri. Hal ini diungkapkan informan aggota persit seperti berikut :

"Ketika zamannya bu jimmy pernah cuma gak kayak sekarang, baru bu devita ini aja, selain itu kan ibu gak punya instagram, kayaknya pake instagram bapak buat ngawasin." (anonym, wawancara 6 agustus 2019)

Selain melalui sosialisasi secara lisan, tidak jarang pula Ibu Ketua Persit mengawasi aktivitas media sosial anggotanya secara langsung, terutama pada pengurus, baik whatsapp maupun instagram. Tidak segan, beliau menegur secara langsung pengurus dan anggota yang dirasa tidak sesuai dalam memposting status di media sosial. Seperti yang diutarakan informan perempuan, anggota persit sebagai berikut:

"Teguran aku udah pernah, Cuma itu terbilang salah faham aja karna mungkin beda daerah beda bahasa, jadi menurut daerah aku artinya apa, menurut daerah lain apa jadi kayak gitu. Teguran langsung, jangan yang gimana - gimana. Ada juga yang saling baper gitu. Kita kadang update buat siapa dan apa, tapi yang ngerasa siapa. Kadang kalau ada yang gak sesuai sama dia jadi salah faham" (anonym, wawancara 6 Agustus 2019)

Pengawasan yang dialami oleh perempuan, anggota persit merupakan pendisiplinan dengan model panopticon yaitu terdapat beberapa aturan dan kode etik tidak tertulis yang membuat perempuan terus merasa diawasi. Secara tidak langsung pengawasan terhadap social media pribadi anggota persit merupakan kekerasan simbolik, dimana korban tidak merasa dia mengalami kekerasan namun merasa bangga atas identitasnya (Bulandari, 2018).

Teguran secara langsung yang diberikan kepada anggota persit dapat menjadi cara preventif yang efektif dalam literasi digital pada perempuan. Namun disisi lain, teguran yang diberikan terkadang sifatnya sangat subjektif, seperti salah faham karna perbedaan budaya, arti dan bahasa dimana si pembuat pesan merasa apa yang disampaikan atau di post merupakan hal yang wajar, namun si penerima merasa itu tidak pantas diungkapkan dalam media sosial.

Menurut Kusworno (2001) Hal ini dikategorikan dalam kegagalan komunikasi primer (kesalahan persepsi atau pemaknaan) jika dibiarkan akan mengakibatkan terganggunya hubungan sosial yang akan berpengaruh kepada hubungan pribadi anggota organisasi.

Beberapa informan mengaku bahwa teguran yang sifatnya tidak substansi membuat mereka merasa tidak nyaman dan cenderung menghindar dari pengawasan ketua dengan cara memblok atau menutupi akses ke media sosial milik mereka. Jika teguran lebih banyak menyasar pada persoalan kecil dan subjektif hal ini tentu dapat menurunkan kredibilitas dari pemimpin.

Menurut Covey untuk membangun komunikasi yang efektif dalam organisasi diperlukan rasa empatik dimana masing - masing individu mencoba untuk mengerti dan memahami karakter dan maksud dan peran orang lain (Knutson,et, al.,2003)

Dalam hal ini peningkatan kompetensi literasi digital bagi ketua persit menjadi hal penting untuk dimiliki, karena ketua memiliki peluang dan otoritas besar dalam mengatur dan mengarahkan anggotanya. Jika kompetensi yang dimiliki rendah, maka hal ini akan mempengaruhi literasi digital perempuan disini anggota persit secara keseluruhan.

Efek dari teguran yang diberikan secara langsung, membuat anggota merasa jera dan lebih mawas diri dalam memposting status maupun informasi di media sosial. Perasaan takut dan trauma menggunakan media sosial juga sempat dirasakan akibat teguran tersebut, namun perasaan itu tidak berlangsung lama. Seperti yang diungkapkan informan perempuan, anggota persit 
sebagai berikut:

"Teguran itu sebenernya jadi buat ngerasa kapok,cuma dari situ jadi mikir memang harus hati - hati kalau mau share apa - apa dan gak semua orang berkenan, dan gak semua bisa satu pikiran sama kita. ya jadi mulai hati-hati. sempet ngerasa males juga si mau posting - posting lagi, cuma lama - lama ya lupa juga" (anonym, wawancara 6 agustus 2019)

Kondisi ini tentu sebagai awalan yang baik untuk meningkatkan literasi digital perempuan pada organisasi persit. Namun dalam hal ini perempuan, anggota persit diharapkan bukan hanya dapat terampil mengakses, menggunakan dan berbagi informasi yang relevan di media digital tapi juga dituntut memiliki kompetensi yang lainnya yaitu menganalisis dan mengevaluasi pesan secara kritis, memproduksi konten yang kreatif dan produktif, serta berkolaborasi dan berpartisipasi dalam lingkungan yang lebih luas (Hobss, 2010).

Berdasarkan hasil wawancara yang telah dilakukan kepada seluruh informan perempuan, anggota persit, dapat digambarkan bahwa perempuan, anggota persit telah memiliki keterampilan dasar dalam kompetensi literasi digital tahap mengakses, menggunakan dan membagi serta memahami informasi, yaitu dengan tidak langsung percaya pada informasi yang diterima melalui media sosial, dan mencoba memverifikasi kembali informasi tersebut melalui berbagai cara antara lain mengecek informasi tersebut melalui goggle atau hastag serupa di media sosial. Mereka juga mengaku tidak langsung memposting atau meneruskan informasi yang mereka terima, jika informasi itu tidak dapat dipertanggung jawabkan kebenarannya.

Selain itu seluruh informan mengerti cara setting keamanan untuk diri sendiri di media sosial dengan lebih memilih menggunakan menu private agar tidak semua orang dapat melihat aktivitas mereka. Hal ini dilakukan untuk menghindari diri dari kemungkinan kejahatan, seperti penyalahgunaan foto dan identitas.

Namun tidak demikian dari hasil observasi yang dilakukan oleh peneliti dengan melihat aktivitas media sosial salah satu informan perempuan, anggota persit, Informan cenderung tidak dapat menerima informasi secara kritis jika informasi yang diterima tidak sesuai dengan preferensi pribadinya terutama yang berakitan dengan tokoh atau public figure tertentu.

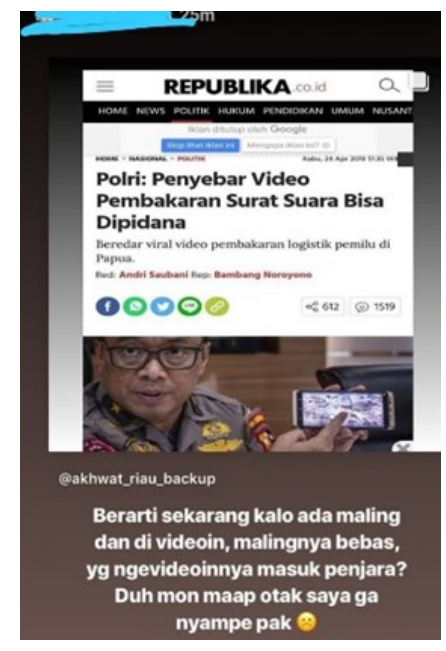

Gb.1. postingan informan perepmpuan, anggota persit pada instagram story

Postingan tersebut dibuat pada masa penghitungan suara pemilihan presiden, april, 2019 lalu. Dimana screenshoot yang dipost dari salah satu media dengan headline yang mengandung clicbait yang tidak sesuai dengan isi beritanya. Informan perempuan, anggota persit menambah dengan status yang menguatkan headline tersebut dimana dapat dipersepsikan bahwa POLRI menangkap penyebar video yang membakar surat suara. Padahal isi beritanya adalah POLRI menangkap penyebar video yang berkonten HOAX.

Fenomena penggunaan media massa dan media social menunjukan tren masyarakat terutama perempuan yang cenderung apatis pada kebenaran sebuah wacana di media (Yudha, 2017). Selain itu informan perempuan, anggota persit juga menyatakan bahwa sempat ditegur karena sering posting mengenai salah satu calon presiden tertentu di media sosial saat masa pilpres, namun informan berdalih bahwa PERSIT memiliki hak suara dan bebas untuk memilih.

Temuan ini menjadi menarik karena secara umum informan memiliki tingkat literasi digital yang cukup baik dalam kompetensi memahami dan membagikan infromasi secara kritis. Namun ketika menyangkut tokoh atau public figure tertentu informan menjadi mudah terprovokasi dan terbawa emosi, apalagi jika sebagian besar anggota persit memiliki preferensi yang sama. 
Infoman perempuan, anggota persit mengaku paling sering menggunakan handphone dan hampir tidak pernah menggunakan laptop atau PC dalam mengakses internet. Mereka menggunakan internet yang utama untuk akses media sosial terutama instagram untuk aktualisasi diri, seperti mengupload kegiatan dan aktivitas sehari - hari terutama kegiatan menjadi anggota persit dan upload foto anak, selain itu juga untuk mencari informasi seputar parenting dan akun gossip dan beberapa informan mengaku sering tergoda untuk mencari produk dan belanja online.

Aplikasi kedua yang sering digunakan adalah whatsapp untuk menjalin pertemanan, menjaga hubungan sosial dan untuk kordinasi kegiatan dan infromasi terbaru yang diinformasikan melalui grup whatsapp, selain itu whatsapp juga di pergunakan untuk memposting status dan foto sebagai ungkapan emosional dan menunjukan eksistensi mereka.

Informan perempuan, anggota persit mengaku memiliki aplikasi Facebook hanya sebatas untuk melihat informasi terbaru, dan platform youtube untuk kebutuhan hiburan seperti mendengarkan music dan menonton video dengan anak. Selain melalui youtube, keempat informan mengakses internet untuk bermain game online seperti game "get rich dan candy crush." untuk mengisi waktu luang.

Hasil penelitian ini berbeda dengan apa yang dinyatakan oleh Rosser, (2005) bahwa game online dibuat oleh laki -laki dan diperuntukan untuk laki laki dengan tampilan yang maskulin, disini perempuan mulai tertarik bermain game melalui internet yang disesuaikan dengan psikologis kesukaan dan perilaku mereka.

Dalam literasi digital perempuan, persoalan yang tidak kalah penting adalah pemahaman mereka dalam memanfaatkan media digital untuk kegiatan yang produktif sehingga dapat meningkatkan nilai dan pengetahuan mereka. Hasil penelitian menunjukan masih terdapat keterbatasan perempuan akan arti penting penggunaan media yang ada. Kecenderungan mereka menggunakan media digital lebih kepada untuk hal yang bersifat konsumtif seperti eksistensi diri dan hiburan. Potter (2005) menyatakan bahwa melalui literasi digital, masyarakat tidak hanya mengerti bagaimana menggunakan media dengan baik, tapi mereka mampu menyinergikan kemudahan teknologi untuk menunjang aktivitas usaha yang produktif.

Kondisi yang terbatas dalam menggunakan media digital pada perempuan dipengaruhi beberapa factor diantaranya kurangnya sosialisasi mengenai pemanfaatan media digital untuk kegiatan yang produktif seperti berjualan online ataupun memanfaatkan media digital untuk memproduksi dan mendistribusikan konten yang baik sehingga memiliki nilai jual.

Hal ini sejalan dengan yang dinyatakan Renggana bahwa hadirnya internet seharusnya dapat memperdayakan perempuan indonesia melalui peluang, misalnya bekerja dan menciptakan belanja online di rumah, sayangnya perkembangan TIK belum terjadi secara otomatis dengan peluang penggunaan internet bagi perempuan di Indonesia (Suwana \& Lily,2017)

Beberapa informan perempuan, anggota persit mengaku telah menggunakan media sosial untuk berjualan online namun belum optimal karena terkendala pada algoritma media sosial yang semakin tidak mudah untuk mempromosikan produk mereka secara gratis.

Selain itu keterbatasan waktu karna harus mengurus pekerjaan domestic rumah tangga seperti mengurus anak, memasak dan membersihkan rumah. Hal ini menjadi salah satu persoalan krusial dalam perspektif gender. Kondisi ini berimplikasi pada stratifikasi pasar tenaga kerja, dimana laki - laki menempati peran strategis dan teknisi dengan bayaran yang lebih tinggi dan perempuan menempati posisi pekerja dengan upah yang lebih rendah bahkan tanpa penghasilan (Rosser,2005).

Seluruh informan perempuan, anggota persit mengaku memiliki keinginan untuk dapat lebih produktif dalam mempergunakan media digital, namun merasa tidak memiliki bakat dan keahlian yang memadai untuk membuat konten - konten bagus di internet . Li \& Kirkup (2007) menunjukkan kepercayaan diri menjadi faktor penghambat bagi perempuan untuk berpartisipasi secara produktif dalam media internet. 


\section{KESIMPULAN}

Kegiatan literasi digital perempuan yang dilakukan oleh organisasi PERSIT Kartika Chandra Kirana pada Skadron 31/ SERBU PUSPENERBAD Semarang, masih sebatas pada sosialisasi dalam aspek kompetensi mengakses dan mendistribusikan informasi untuk menjaga citra institusi TNI AD.

Ketua Persit menjadi faktor penting dalam keberhasilan literasi digital perempuan pada organisasi PERSIT. Ketua memiliki wewenang yang besar untuk menentukan jalannya organisasi dan masih sangat dihormati dan disegani oleh pengurus dan anggota. Teguran dan pengawasan langsung secara personal yang dilakukan oleh ketua persit menjadi tahap preventif yang cukup efektif dalam literasi digital perempuan. Namun disisi lain cara ini membuat anggota merasa diawasi dan tidak nyaman bahkan merasa trauma menggunakan media sosial.

Pemanfaatan media digital perempuan pada anggota PERSIT masih sebatas konsumtif, yakni menggunakan media digital paling banyak untuk akses media sosial yakni ; WhatsApp, Instagram, Facebook, Youtube bertujuan untuk eksistensi diri dan hiburan, serta mencari informasi seputar parenting. Perempuan, anggota PERSIT memiliki keinginan mempergunakan media digital untuk tujuan yang lebih produktif seperti berjualan online, namun terkendala waktu karena mengurus keperluan domestik keluarga, tidak mengerti cara pemasaran yang efektif dan kurangnya kepercayaan diri.

Perempuan, anggota PERSIT secara umum telah memiliki kemampuan yang cukup baik dalam menerima dan mendistribusikan konten dengan kritis, mereka mengetahui cara memverifikasi informasi dan mengaku tidak mudah share jika infromasi belum bisa dibuktikan kebenarannya. Namun dari hasil observasi dengan melihat aktivitas media sosial informan, peneliti menemukan bahwa beberapa informan perempuan, anggota PERSIT mem-publish status yang cenderung mengandung miss infromasi terutama berkaitan dengan tokoh atau public figure tertentu, terutama saat masa PILPRES April 2019 yang lalu. Perempuan anggota PERSIT cenderung defensif jika ditegur atau di- peringati jika infromasi yang dibagikan sesuai dengan preferensinya, dengan dalih PERSIT memiliki hak untuk memilih.

Kegiatan literasi digital pada perempuan sepatutnya tidak dimaknai sempit hanya sebatas pada pengetahuan kognitif penggunaan media sosial dengan baik. Perkembangan teknologi sepatutnya dapat dimaknai sebagai peluang bagi pemberdayaan perempuan untuk menjadi ibu rumah tangga sekaligus insan yang produktif dan kreatif.

Kontribusi penelitian ini berupa masukan kebijakan mengenai kegiatan literasi yang dilakukan dengan menempatkan kelompok kohesif dalam hal ini perempuan dalam organisasi persit sebagai subjek dalam kegiatan literasi yang terus berjalan.

\section{DAFTAR PUSTAKA}

APJII. (2017). Survey Nasional Penetrasi Pengguna Internet 2017. Asosiasi Penyelenggara Jasa Internet Indonesia.

Banyumurti, I. (2019). Seri Literasi Digital : Demokrasi Damai Era Digital. Jakarta : Siberkreasi

Bulandari,P.H. (2018). Analisa Proses Komunikasi Atas Normalisasi Konsep Panopticon dalam Organisasi Bhayangkari.Interkasi Jurnal Ilmu Komunikasi,7 (1), 54-68.

Daily Socia.Id : Distribusi Hoax di Media Sosial (2018). Tersedia dari: https://dailysocial.id/post/ laporan-dailysocial-distribusi-hoax-di-media-sosial2018

Herlina,D., Setiawan,B. \& Jiwana,G. (2018). Digital Parenting : Mendidik Anak di Era Digital. DIY : Samudra Biru

Hobbs,R. (2010). Digital and media literacy a plan of action: White paper. Washington,DC: The Aspen Institute.

Konutson, T.J., Komolsevin, R., Chatiketu, P., Smith, V.R., (2003). A cross cultural comparason of Thai and US American rethorical sensitivity implications for intercultural communication effectiveness. International Journal of Intercultural Relation, 27 (1), 63-78. 
Kurnia,N., Astuti, S.I. (2017). Peta Gerakan Literasi Digital di Indonesia: Studi Tentang Pelaku, Ragam Kegiatan, Kelompok Sasaran dan Mitra. Informasi Kajian Ilmu Komunikasi, 47(2), 149 -166.

Kuswarno, E. (2001). Efektivitas Komunikasi Organisasi. Mediator, 2(1), 55-61.

Li,N., Kirkup.G. ( 2007). Gender and cultural differences in Internet use: A study of China and the UK. Computers \& Education, 48, 301 - 317. doi : 10.1016/ j.compedu.2005.01.007

Potter, James W. (2005). Media Literacy. London: Sage Publication

Rai, A. (2019). Digital Divide: How Do Women in South Asia Respond?. International Journal of Digital Literacy and Competence, 10(1), 1-14. doi: 10.4018/ IJDLDC.2019010101

Rahmiaji, L. R. ( 2019). Seri Literasi Digital : Demokrasi Damai Era Digital. Jakarta : Siberkreasi

Rakhmat,J. (2015). Psikologi Komunikasi (3th ed). Bandung : PT Remaja Rosdakarya Offset.

Rosse,S.V. (2005). Through the Lenses of Feminist Theory: Focus on Women and Information Technology. A Journal of Women Studie, 26 (1), 1-23.

Rousseau, J.S and Puttaraju, K. (2014). A Study of Gender Differential Factors in the uses of Social Networking Sites. International Journal of Humanities and Social Science Innovation, 3(2), 31 - 40.

Suwana, F., Lily. (2017) Empowering Indonesian women through building digital media literacy. Kasetsart Journal of Social Sciences, 38, 212 -217.

Tubbs,S.L., Moss,S. (2000). Human Communications : Konteks Komunikasi (2th ed). Bandung : PT Rosda Yuda, R.P. (2017) Tantangan Literasi Era Media Digital (Analisa Pengguna Media berdasarkan Model Kemungkinan Elaborasi). Interaksi Jurnal Ilmu Komunikasi, 6 (1), 132-139. 